\title{
PERAN GURU DALAM MENEGAKKAN TATA TERTIB SEKOLAH DI SDN 006 BUKIT KAPUR KOTA DUMAI
}

\author{
Doni Setiawan ${ }^{1}$, Elpri Darta Putra ${ }^{1}$ \\ ${ }^{1}$ Universitas Islam Riau, Pekanbaru \\ *Corresponding Address: doni.setiawan@student.uir.ac.id
}

Naskah diterima: 1 November 2021| Disetujui: 8 November 2021 | Diterbitkan: 14 November 2021

\begin{abstract}
Abstarct: The role of the teacher in the school environment is not only as a teacher, there are so many teacher roles that the teacher must carry out. One of the teacher's roles in schools is to enforce school rules, where this order is very important to carry out so that discipline is embedded in students. In this study, the main objective is to describe how the role of teachers in enforcing school rules and regulations. Techniques for collecting the data needed in this study used interview, observation, and documentation techniques. To manage the data using an interactive analysis model from Miles and Huberman, namely collecting data, reducing data, presenting data, and drawing conclusions. In this study resulted in a style of role performed by the teacher such as using a role style that is seen in the process undertaken by the teacher in supervising students, making decisions, and enforcing rules and acting in determining a solution or problem that arises.
\end{abstract}

Keywords: Teacher's Role, Code of Conduct.

Abstrak: Peran guru dalam lingkungan sekolah tidak hanya sebagai pengajar saja, begitu banyak peran guru yang harus guru jalankan. Salah satu peran guru di sekolah seperti menegakkan tata tertib sekolah, dimana tata tertib ini sangat penting dijalankan agar tertanamnya kedisiplinan di dalam diri siswa. Tujuan penelitian ini untuk mendeskripsikan bagaimana peran guru dalam menegakkan tata tertib sekolah. Teknik untuk mengumpulkan data yang dibutuhkan dalam penelitian ini menggunakan teknik wawancara, observasi, dan dokumentasi. Analisis data menggunakan analisis interaktif model dari Miles dan Huberman yang meliputi pengumpulan data, reduksi data, penyajian data, dan penarikan kesimpulan. Dalam penelitian ini menghasilkan suatu gaya peran yang dilakukan oleh guru seperti menggunakan gaya peran yang terlihat pada proses yang dijalani guru dalam kegiatan mengawasi siswa, mengambil keputusan, serta menegakkan tata tertib dan bertindak dalam mementukan suatu solusi ataupun masalah yang muncul.

Kata kunci: Peran Guru, Tata Tertib. 


\section{PENDAHULUAN}

Pendidikan nasional berfungsi untuk mengembangkan kemampuan dan membentuk watak serta peradaban bangsa yang bermartabat dalam rangka mencerdaskan kehidupan bangsa. Menurut Nurkholis, pendidikan merupakan proses yang dibutuhkan untuk mendapatkan keseimbangan dan kesempurnaan dalam perkembangan individu maupun masyarakat (Nurkholis, 2013). Tertuang dalam Undang-undang No.20 tahun 2003 tentang Sistem Pendidikan Nasional yang mentebutkan bahwa pendidikan adalah unsur sadar dan terencana untuk mewejudkan suasana belajar dan proses pembelajaran agar peserta didik secara aktif mengembangkan potensi dirinya untuk memiliki kekuatan spiritual keagamaan, pengendalian diri, kepribadian, kecerdasan, akhlak mulia, serta keterampilan diperlukan dirinya, masyarakat, bangsa dan negara. Menurut Sudarwan, guru bermakna sebagai pendidik professional dengan tugas utama mendidik, mengajar, membimbing, mengarahkan, melatih, menilai, dan mengevaluasi peserta didik pada jalur pendidikan formal. Guru itu digugu dan ditiru apabila guru berperilaku tidak baik maka siswa akan meniru perilaku guru tersebut, dan apabila guru itu berperilaku baik didepan siswa maka siswa pun akan mencontoh prilaku guru yang baik tersebut (Wini, 2020). Menurut Mulyasa, guru adalah pendidik, yang menjadi tokoh, panutan, dan identifikasi bagi para peserta didik, dan lingkungannya. Oleh karena itu, guru harus memiliki standar kualitas pribadi tertentu, yang mencangkup tanggung jawab, wibawa, mandiri, dan disiplin (Mulyasa, 2015).

Guru merupakan komponen utama di dalam pendidikan sekolah, apapun yang guru terapkan di sekolah maka akan dicontoh oleh siswa, guru juga salah satu orang tua kita saat di sekolah yang mengajarkan peserta didik dalam pengetahuan, materi dan tingkah laku yang lebih baik. Guru adalah orang tua siswa di sekolah (Mumtahanah, 2018). Sebagai orang tua di sekolah memang seharusnya guru bertanggung jawab terhadap perkembangan siswanya baik dari segi kognitif, afektif dan psikomotorik. Guru adalah pendidik, yang menjadi tokoh, panutan, dan identifikasi bagi para peserta didik, dan lingkungannya. Oleh karena itu, guru harus memiliki standar kualitas pribadi tertentu, yang mencangkup tanggung jawab, wibawa, mandiri, dan disiplin. Sebelum melakukan penelitian ini, peneliti mencari penelitian yang berkaitan dengan masalah yang peneliti temukan dilapangan sebagai panduan dalam mengembangkan penelitian ini serta pembaharuan dari penelitian sebelumnya. Tujuan tata tertib sekolah sangat penting. secara umum dibuatnya tata tertib sekolah mempunyai tujuan utama agar semua warga sekolah mengetahui apa tugas, hak dan kewajiban, serta melaksanakan dengan baik sehingga proseskegiatan sekolah dapat berjalan dengan lancer (Meti, dkk, 2019). Penelitian sebelumnya hanya berfokus dengan tata tertib sekolah tanpa melihat bagaimana peran guru selama di sekolah dalam menegakkan tata tertib, maka dari itu peneliti menambahkan 
komponen dalam penelitian ini seperti mengumpulkan data melalui guru serta orang yang terlibat dalam sekolah tersebut.

Berdasarkan wawancara yang dilakukan dengan salah satu guru di SDN 006 Bukit Kapur yang bernama Ibu Herliati, S. Pd. mengemukakan ada beberapa persoalan yang berkaitan dengan tata tertib yaitu: 1) kurang kedisiplinan dalam berpakaian; 2) siswa berkelahi dengan siswa lain; 3) kurang disiplinnya siswa dalam menjaga kebersihan; 4) siswa datang terlambat. Berdasarkan kondisi ini jelas terdapat kurangnya kesadaran masyarakat sekolah dalam menegakkan tata tertib karena masih banyak pelanggaran tatat tertib yang dilakukan siswa sehingga ada beberapa siswa yang sering melakukan pelanggaran dan ada beberapa guru yang kurang tegas dalam menangani pelanggaran yang siswa lakukan sehingga siswa beranggapan hal itu hal yang sepele. Kepatuhan terhadap peraturan tata tertib sekolah merupakan sebuah kesiapan yang harus ditanamkan dalam diri siswa disekolah agar mempunyai sikap sosial dan bertanggung jawab dalam menaati sebuah peraturan.

Dari permasalahan yang peneliti temukan di sekolah dasar serta penelitian sebelumnya yang peneliti analisis dari permasalahan yang ada dalam penelitian sebelumnya maka penelitian ini dilakukan dengan judul "Peran Guru dalam Menegakkan Tata Tertib Sekolah Di SDN 006 Bukit Kapur Kota Dumai".

\section{METODE}

Jenis penelitian ini adalah penelitian deskriptif dengan pendekatan kualitatif. Penelitian deskriptif adalah suatu bentuk penelitian yang ditujukan untuk mendeskripsikan atau menggambarkan fenomena-fenomena yang ada, baik fenomena alamiah maupun rekayasa manusia. Dalam penelitian kualitatif ini berbentuk data fakta peran guru dalam menegakkan tata tertib sekolah. Penelitian ini dilaksanakan di SDN 006 Bukit Kapur, Jalan Pendidikan, Kelurahan Bukit Kayu Kapur, Kecamatan Bukit Kapur, Kota Dumai.

Dalam penelitian ini peneliti bertindak sebagai key instrument dalam pengumpulan data yang secara langsung turun ke lapangan secara aktif. Dalam penelitian ini pengumpulan data dilakukan dengan beberapa teknik sesuai dengan data apa yang dibutuhkan, di antaranya (1) Observasi, (2), Wawancara, dan (3) Dokumentasi. Miles dan huberman mengemukakan bahwa aktivitas dalam analisis data kualitatif dilakukan secara interaktif dan berlangsung secara terus menerus sampai tuntas, sehingga datanya sudah jenuh (Sugiyono, 2016). 


\section{HASIL DAN PEMBAHASAN}

SDN 006 Bukit Kapur mempunyai aturan terkait tata tertib sekolah yang harus ditaati oleh seluruh SDN 006 bukit Kapur. Sesuai dengan dokumen yang diberikan oleh pihak sekolah yaitu dalam waktu dan tempat pelaksaan kegiatan pembelajaran. Dalam pelaksanaan kegiatan pembelajaran tidak dibenarkan berada di luar kelas pada saat kegiatan pembelajaran berlangsung tanpa seizin guru. Hal ini didukung dengan wawancara kepada guru di SDN 006 Bukit Kapur.

Setiap anak yang melanggar tata tertib sekolah akan mendapat sanksi, misalnya anak yang datang terlambat masuk kelas maka tidak boleh mengikuti pelajaran sebelum mendapat izin dari guru piket atau siswa berdiri di depan kelas untuk menghafal surah pendek, lagu wajib, dan lainnya sebagai jika guru piket tidak ada. Untuk mewujudkan situasi yang tertib sebuah lembaga pendidikan guru

yang sering bertanggung jawab untuk menyampaikan dan mengontrol berlakunya tata tertib. Tata tertib bisa berjalan apabila ada kerjasama antara guru dan siswa. Akan tetapi apabila tata tertib bi sa berjalan, maka tata tertib bisa dibagi menjadi dua yaitu ada yang berlaku untuk umum (seluruh lembaga pendidikan). Maksudnya, sebuah tata tertib yang diberlakukan untuk semua kalangan yang ada di lembaga itu, ada pulak yang khusus (hanya untuk di kelas). Maksudnya adalah tata tertib ini diberlakukan untuk siswa saja. Tidak berlaku untuk guru dan karyawan. Semua tata tertib, baik yang berlaku untuk umum. Maupun untuk khusus meliputi tiga unsur, yaitu: (a) perbuatan atau perilaku yang diharuskan dan yang dilarang. Contohnya jika terlambat dating harus melapor ke bagian pengajaran untuk memperoleh surat keterangan terlambat harus diserahkan kepada guru yang sedang mengajar; (b) akibat atau sanksi yang menjadi tanggung jawab pelanggar tata tertib. Contohnya jika terlambat datang tetapi tidak melapor kebagian pengajaran dianggap tidak masuk sekolah dan setibanya tidak diizinkan mengikuti pelajaran; (c) cara atau prosedur untuk menyampaikan tata tertib subjek yang dikenai tata tertib tersebut. Contohnya peraturan tentang keterlambatan datang kesekolah dikomunikasikan kepada siswa dan orang tua siswa secara tulisan pada waktu mereka mendaftar kembali sesudah dinyatakan diterima di sekolah yang bersangkutan.

Dari analisis penerapan tata tertib sekolah di SDN 006 Bukit Kapur mengenai peraturan tata tertib sekolah tentang waktu dan tempat pelaksanaan kegiatan pembelajaran yaitu siswa tidak dibenarkan berada di luar kelas tanpa seizin dari guru dan siswa yang terlambat dalam mengikuti pembelajaran atau terlambat masuk kelas, maka akan diberi sanksi oleh guru.

Pakaian seragam dan kelengkapannya, siswa SDN 006 Bukit Kapur diwajibkan berpakaian rapi, bersih dan sopan, dan memakai pakaian seragam yang telah ditentukan oleh sekolah. Berdasarkan wawancara diperoleh hasil sebagai bahwa tata tertib di SDN 006 Bukit Kapur sudah terlaksana, seperti upacara bendera yang diadakan setiap hari senin, siswa memakai seragam sesuai 
ketentuan sekolah, masuk dan pulang sesuai dengan jam yang telah ditentukan, sholat dhuha dan sholat duhur berjamaah.

Pakaian seragam tidak berarti hanya pakaian sebagai identitas, melainkan bentuk pendisiplinan. Pemakaian seragam sekolah kepada siswa di sekolah bertujuan untuk membuat siswa mudah diarahkan, diatur, serta agar siswa berdisiplin diri. Selain itu terkait pelaksanaan kegiatan upacara siswa harus menggunakan seragam lengkap yang sudah diatur di dalam tata tertib sekolah.

Keseragaman merupakan komponen cermin keindahan, namun bila ada yang berbeda akan menimbulkan kesan yang kurang sedap dipandang. Dari hasil analisis penerapan tata tertib sekolah tentang pakaian seragam dan kelengkapannya, siswa diwajibkan untuk berpakaian rapi, bersih dan sopan, dan juga memakai atribut lengkap. Kemudian siswa harus memakai seragam yang telah ditentukan oleh sekolah. Khususnya untuk mengikuti kegiatan upacara, siswa diharapkan dapat tertib dalam berseragam serta dapat mengikuti kegiatan upacara dengan baik. Siswa juga masuk dan pulang sekolah harus sesuai dengan yang ditetapkan oleh sekolah.

Dalam penerapan tata tertib sekolah salah satunya siswa harus mematuhi tata tertib sekolah terkait tentang pelaksanaan ibadah. Siswa wajib mengikuti kegiatan imtaq hari jumat, dan wajib mengikuti kegiatan-kegiatan keagamaan yang ada di sekolah. Siswa diwajibkan mengikuti kegiatan tersebut, supaya terlatih ketika di rumah maupun lingkungan dan membentuk akhlak yang baik. Hal ini didukung wawancara dengan guru di SDN 006 Bukit Kapur,

"Jadi semisal imtaq jumat, saya mengarahkan siswa untuk mengikuti kegiatan tersebut. Kemudian ketika ada siswa yang tidak mengikuti kegiatan keagamaan yaitu dengan cara memberi sanksi atau denda. Jadi peran saya dalam menegakkan tata tertib yaitu lebih tepatnya sebagai pembimbing".

Ibadah menurut bahasa artinya taat, tunduk, turut, ikut, dan doa. Ibadah dalam makna taat atau mentaati (diperintahkan). Ibadah adalah segala sesuatu yang diridhoi Allah baik berupa perbuatan, perkataan, untuk menyatakan bakti kepada Allah yang didasari mengerjakan perintahNya.

Dari analisis penerapan tata tertib sekolah mengenai pelaksanaan kegiatan ibadah atau keagamaan, siswa harus mengikuti kegiatan keagamaan mulai dari sholat dhuha dan sholat dzhuhur berjamaah. Kemudian mengikuti kegiatan keagamaan yang sudah ditetapkan oleh pihak sekolah. Semua itu dilakukan untuk merubah perilaku siswa agar memiliki akhlak yang baik. Maka dari itu sangat penting sekali pelaksanaan ibadah ini di dalam tata tertib sekolah.

Penerapan tata tertib sekolah di SDN 006 Bukit Kapur juga membahas tata tertib tentang perilaku siswa. Tata tertib tentang perilaku siswa ini salah satu peraturannya adalah siswa wajib 
bersikap dan berperilaku sopan, menghormati b apak/ibu guru dan karyawan, bertutur kata yang baik di sekolah maupun diluar sekolah. Kemudian siswa juga wajib menjaga keamanan, ketertiban, kebersihan, keindahan, dan kenyamanan sekolah. Siswa juga wajib mematuhi tata tertib sekolah yang sudah ditetapkan sekolah. Hal ini sebagaimana yang telah diungkapkan oleh Bapak Qomari selaku Kepala Sekolah SDN 006 Bukit Kapur bahwa tujuan dari tata tertib sekolah yaitu menertibkan siswasiswi SD agar terbiasa hidup tertib. Tujuan utama tata tertib dibuat agar semua warga sekolah mengetahui apa tugas, hak dan kewajiban serta melaksanakan dengan baik sehingga kegiatan sekolah dapat berjalan dengan lancar. Tujuan yang lainnya yaitu supaya anak berbuat tertib dan berperilaku yang baik. Sejalan dengan pendapat Fawaid, tujuan utama tata tertib adalah melatih disiplin dan menanamkan disiplin moral dalam diri individu yang akan membentuk pola perilaku, sehingga tata tertib menjadi sebuah kontrol perilaku agar sesuai dengan peraturan (Fawaid, 2017). Dalam konteks pendidikan, masyarakat merupakan lingkungan ketiga setelah keluarga dan sekolah. Masyarakat dapat memberi pengaruh terhadap perilaku anak, membentuk kebiasaan pengetahuan anak (Prasetyo dan Irwansyah, 2020).

Dari analisis penerapan tata tertib sekolah mengenai perilaku siswa, siswa harus bersikap dan berperilaku sopan terhadap semua warga sekolah, serta mematuhi peraturan tata tertib sekolah supaya kegiatan sekolah dapat berjalan dengan baik, dan lancar. Siswa harus berperilaku yang baik dan akhlak yang baik, dan menjaga nama baik sekolah.

Menurut Kirom, peran (role) guru merupakan keseluruhan perilaku yang harus dilakukan guru dalam melaksanakan tugasnya sebagai guru. Guru mempunyai peranan yang luas, baik di sekolah, di dalam keluarga, maupun masyarakat (Kirom, 2017). Di SDN 006 Bukit Kapur guru dalam menegakkan tata tertib sekolah sudah menjalankan perannya dengan baik, yaitu dengan melaksanakan tugasnya sebagai guru. Guru mengawasi, memeriksa, dan memberi tindak lanjut kepada siswa yang melanggar peraturan tata tertib sekolah. Memberikan hukuman pada siswa yang melanggar peraturan tata tertib sekolah. Selain mengawasi, memeriksa, dan memberi tindak lanjut, guru juga berperan sebagai penghubung, pembimbing dan membangun komunikasi pihak sekolah dengan orang tua murid, dan juga siswa. Terbentuknya kedisiplinan tersebut tentunya adanya peran guru di sekolah yang selalu memberi nasihat dan memberi contoh kepada siswanya untuk melakukan kegiatan disiplin (Kharisma dan Suyatno, 2014). Jadi, guru adalah orang dewasa yang secara sadar bertanggung jawab dalam mendidik, mengajar, dan membimbing peserta didik agar dapat belajar dan pada akhirnya dapat mencapai tingkat kedewasaan sebagai tujuan akhir dari proses pendidikan (Heriansyah, 2018). 
Guru menjadi peran utama dalam terlaksananya tata tertib sekolah dengan baik. Guru memiliki peran yang sangat penting dalam menegakkan tata tertib sekolah. Maka dari itu, tidak terlaksananya penerapan tata tertib sekolah yaitu dari pengaruh tim pengeksekusi atau dari pihak guru. Kurang tegasnya seorang guru juga sangat berpengaruh.

Di sekolah ia berperan sebagai perancang pengajaran, pengelola pengajaran, penilai hasil pembelajaran, pengarah pembelajaran, dan sebagai pembimbing siswa. Di dalam keluarga guru berperan sebagai pendidik atau family educator. Sedangkan di masyarakat, guru berperan sebagai pembina masyarakat (social developer), pendorong masyarakat (social motivator), penemu masyarakat (social innovator), dan sebagai agen masyarakat (social agent). Guru yang baik dan efektif adalah guru yang dapat memainkan semua peranan itu secara baik dan utuh.

Menganalisis lebih jauh mengenai hasil penelitian pada Bab IV tentang peran guru dalam menegakkan tata tertib sekolah, tidak bisa di pungkiri bahwa memang guru memegang peranan yang sangat penting. Dari hasil wawancara dari beberapa guru di SDN 006 Bukit Kapur, mulai terlihat peran guru sebagai pengawas, memeriksa pelaksanaan kemudian memberi tidak lanjut, sebagai penghubung, pengkomunikasi antara pihak sekolah dan orangtua murid dan juga siswa, berperan sebagai pembimbing, evaluator, supervisor, dan bertindak tegas terthadap siswa yang melanggar tata tertib sekolah.

Dari hasil analisis data penelitian ditemukan bahwa peran guru dalam menegakkan tata tertib sekolah di SDN 006 Bukit Kapur selalu mengontrol atau mengawasi jalannya tata tertib sekolah, mulai dari mngontrol program-program sekolah dengan mengaktifkan kegiatan ekstrakurikuler yang juga masuk dalam daftar tata tertib sekolah, mengontrol peraturan tentang tugas dan kewajiban dalam kegiatan sekolah, sampai mengontrol larangan/bentuk pelanggaran bagi siswa, dan juga mengontrol dalam kegiatan keagamaan. Hal ini menunjukkan bahwa guru di SDN 006 Bukit Kapur sudah menjalankan perannya dengan baik, dengan menjalankan salah satu fungsi manajement yaitu Controlling (pengontrolan).

Pada saat kegiatan sekolah sedang bergerak atau berjalan, kepala sekolah harus selalu mengadakan pengawasan atau pengendalian agar gerakan atau jalannya kegiatan operasinonal sekolah sesuai dengan planning yang telah digariskan. Fase ini disebut "pengawasan atau pengendalian" (controlling).

Secara keseluruhan dari hasil analisis mengenai peran guru dalam menegakkan tata tertib sekolah sudah maksimal terlaksana dengan baik, namun terkendala di penerapan tata tertib sekolah. Peran guru dalam menegakkan tata tertib sekolah berbeda-beda. Ada yang perannya mengawasi dan memeriksa pelaksanaannya yang kemudian memberi tindak lanjut, sebagai penghubung dan 
pengkomunikasi dalam menghadapi siswa, dan ada juga yang berperan sebagai pembimbing. Guru sudah menjalankan perannya dengan baik dalam menegakkan tata tertib sekolah. Maka dari itu diperlukan tindakan yang tegas dari pihak guru dalam menegakkan tata tertib sekolah di SDN 006 Bukit Kapur

\section{KESIMPULAN}

Peraturan tata tertib sekolah tentang waktu dan tempat pelaksanaan kegiatan pembelajaran yaitu siswa tidak dibenarkan berada di luar kelas tanpa seizin dari guru dan siswa yang terlambat dalam mengikuti pelajaran atau terlambat masuk kelas, maka akan diberi sanksi oleh guru. Siswa diharapkan dapat mematuhi peraturan tata tertib yang ada. Penerapan tata tertib sekolah terkait tata tertib tentang pakaian seragam dan kelengkapannya, siswa diwajibkan untuk berpakaian rapi, bersih dan sopan, dan juga memakai atribut lengkap. Kemudian siswa harus memakai seragam yang telah ditentukan oleh sekolah. Khusus untuk mengikuti kegiatan upacara, siswa diharapkan dapat tertib dalam berseragam serta dapat mengikuti kegiatan upacara dengan baik. Siswa juga masuk dan pulang sekolah harus sesuai dengan yang ditetapkan oleh sekolah.

Penerapan tata tertib sekolah terkait tata tertib tentang pelaksanaan ibadah, siswa diwajibkan untuk mengikuti kegiatan keagamaan di sekolah, khususnya kegiatan keagamaan sholat dhuha dan sholat duhur berjamaah. Untuk itu diharapkan siswa SDN 006 Bukit Kapur dapat mengikuti kegiatan keagamaan tersebut. Apabila siswa tidak mengikuti kegiatan keagamaan tersebut, maka akan ada tindak lanjut dari sekolah utuk memberikan sanksi atau hukuman. Maka dari itu diharapkan siswa dapat mentaati tata tertib sekolah terkait pelaksanaan ibadah.

Siswa harus bersikap dan berperilaku sopan terhadap semua warga sekolah, serta mematuhi peraturan tata tertib sekolah agar kegiatan sekolah dapat berjalan dengan baik, dan lancar. Guru juga harus mengawasi siswa untuk meyakinkan bahwa semua peraturan tata tertib sekolah dapat terlaksana dengan baik dan dipatuhi oleh siswa. Mengawasi semua kegiatan atau tindakan siswa terutama di lingkungan sekolah. Guru juga diharuskan membimbing siswanya memberikan bantuan kepada siswa agar mereka mampu menemukan masalahnya sendiri, memecahkan masalahnya sendiri, mengenal diri sendiri, dan menyesuaikan diri dengan lingkungannya. Oleh karena itu, perlu ada bimbingan atau bantuan dari guru supaya siswa dapat mengatasi kesulitan-kesulitan atau masalah yang dihadapi siswa. Sebagai edukator, guru harus memberikan teladan atau contoh pada siswa seperti datang lebih awal, membuang sampah di tempatnya, selalu ikut menjalankan shalat berjamaah, dan untuk memberikan efek jera kepada siswa, kemudian memberi tindak lanjut dan hukuman pada siswa yang melanggar tata tertib sekolah. 


\section{DAFTAR PUSTAKA}

Meti, Maria Diana. Suciati \& Didik Iswahyudi (2019). Prosiding Seminar Nasional Pendidikan dan Pembelajaran Bagi Guru dan Dosen. (Vol 3, Tahun 2019)

Mulyasa. (2015). Menjadi Guru Profesional. Bandung: Remaja Rosdakarya

Mumtahanah. (2018). Peranan Guru Pendidikan Agama Islam Dalam Mengatasi Perilaku Menyimpang Siswa. Jurnal Pendidikan Agama Islam (Volume 3 No.1, Januari - Juni 2018)

Nurkholis. (2013). Pendidikan dalam upaya memajukan teknologi. Jurnal Kependidikan, (Vol. 1 No. 1 Nopember 2013)

Irwansa, A., \& MAF’UL, M. A. (2016). Analisis pelaksanaan tata tertib sekolah pada siswa di smk negeri 1 makassar. Jurnal Tomalebbi, 2(1).

Wini, (2020). Peran Guru Dalam Menangani Pelanggaran Disiplin Siswa Di Sekolah Menengah Kejuruan Negeri 02 Tembilahan Kota. Asatiza, Jurnal Pendidikan (Vol 1, No1, Januari - April 2020).

Nuriyah, E. S. (2015). Tata Tertib Sekolah Sebagai Sarana Pendidikan Karakter Di SDN Pekuwon III Sumberejo Tahun Pelajaran 2011/2012. Jurnal Pendidikan Edutama, 2(1).

Suyitno, I., \& Rasyid, M. (2019). Kontribusi Tata Tertib Sekolah Terhadap Prestasi Belajar PKN Siswa Pada SMP Negeri 1 Bajeng Kabupaten Gowa. SUPREMASI: Jurnal Pemikiran, Penelitian Ilmu-ilmu Sosial, Hukum dan Pengajarannya, 13(2).

Puspitaningrum, D., \& Suyanto, T. (2014). Implementasi Tata Tertib Sekolah Dalam Membentuk Disiplin Siswa di SMP Negeri 28 Surabaya. Kajian Moral dan Kewarganegaraan, 2(2).

Syaifuddin, M. (2017). Pembentukan Budaya Disiplin Melalui Program Penegak Disiplin Sekolah di SMAN 1 Porong Kabupaten Sidoarjo. Kajian Moral dan Kewarganegaraan, 5(01).

Darwati, G. M. (2015). Implementasi Tata Tertib Sekolah Dalam Menanggulangi Kenakalan Remaja Pada Siswa Kelas VII SMP Dwijendra Denpasar Tahun Pelajaran 2015/2016. Widya Accarya, 4(1).

Komalaningrum, A. L., Sofyan, D., \& Jauhari, D. R. (2018). Peranan Tata Tertib Sekolah Terhadap Peningkatan Prestasi Belajar Siswa SMA. FOKUS (Kajian Bimbingan \& Konseling dalam Pendidikan), 1(1).

Mardawani, M. (2015). Ketaatan Siswa dalam Mematuhi Tata Tertib Sekolah (Studi Kasus Pada Siswa SMA Nusantara Indah Sintang). VOX EDUKASI: Jurnal Ilmiah Ilmu Pendidikan, 6(1). 
Rohman, F. (2018). Peran Pendidik Dalam Pembinaan Disiplin Siswa di Sekolah/Madrasah. Ihya alArabiyah: Jurnal Pendidikan Bahasa dan Sastra Arab, 4(1).

Ghofur, A., \& Nazaruddin, M. (2020). Pola Pembinaan Kedisiplinan Peserta Didik di Sekolah Menengah Kejuruan Pertanian Pembangunan Negeri Sembawa. Muaddib: Islamic Education Journal, 3(2). 